\title{
Swami Vivekananda's Introspection on Education: A Study based on 24 Parganas(s), West Bengal, India
}

\author{
Subhadeep Dutta \\ B.Com (CU) and CA (ICAI) Student, WB, India \\ subhadutta855@gmail.com
}

\begin{abstract}
Education is part and parcel of our life we cannot live without education so education is called the backbone-mirror of our society. Human-being is superior to other animals, animals can be trained but human-beings can be educated. Education is a dynamic process that starts from birth and continues until death. Education has two major parts first one is social education and the second one is formal education both are the dependent variable with each other. This project mainly deals with formal education, the study analysis of different aspects which will affect our education system in SOUTH 24 PARGANAS DISTRICT. The research design undertaken for the study was descriptive research and the convenience sampling method is used and the sample size consists of 200 respondents. Only a simple percentage analysis method used to analyze collected data and results of the study shows that education system has both positivenegative impacts on teachers, students and guardians' satisfaction.
\end{abstract}

Keywords:

Education; CBCS; Rural higher-education; Swami Vivekananda's; Teachers' and Students' Philosophy.

This is an open access article under the CC-BY-NC license.

\section{INTRODUCTION}

We all know human beings-youths-childrenstudents are assets for every nation in particular and the world in general. Beforehand, many educationalists compare children with soil-flowersseeds-ornament. Therefore as teacher-professoreducationalist-guide-trainer, we have had responsible to build nation healthfully through its lengthy-hardy process. In this process, education plays a major role in making democracy more meaningful-relevant and to build-up or develop the socio-economic nation. I think that, having many similarities between the educations and manufacturing sector-industry.In the present era, education is a good business sector and it becomes a manufacturing industry where teacher-professoreducationalist-guide-traineris manufacturer and student-trainees raw materials similarly, after the process we get both finished goods like-regularentered-social students and un-finished goods likeunsocial dropout students. However, Highereducation sector has witnessed a tremendous increase in the number of Universities level Institutions and Colleges since Independence. The quantum growth in the higher education sector is spearheaded by Universities, which are the highest seats of learning. In India, 'University' means a University established or incorporated by or under a Central Act or Provincial Act or State Act and includes any such institution as may, in consultation 
with the University concerned, be recognized by the within the country and abroad, enter these portals University Grants Commission (UGC) in accordance mainly for their graduate, post-graduate studies with the regulations made in this regard under the while millions leave these portals for the world UGC Act, 1956. Every year, millions of students from outside.

Figure 1: Indian Education System

\begin{tabular}{|l|l|}
\hline Step - I & - Nursery (LKG \& UKG) \\
\hline Step - II & - Primary (Class - 1 to 5) \\
\hline Step - III & - Secondary (Class - 6 to 10) \\
\hline Step - IV & - Higher Secondary (Class - 11 \& 12) \\
\hline Step - V & - Graduation (Degree or Professional Course) \\
\hline Step - VI & - Post Graduation (Master or Professional Course) \\
\hline
\end{tabular}

\section{THEORETICAL PERSPECTIVES}

\section{Concept of Education}

Education is the process of facilitating learning or acquisition of knowledge, skills, values, beliefs, and habits. Educational methods include storytelling, discussion, teaching, training, and directed research. In most regions, education is compulsory up to a certain age. In English 'Education' came from four Latin words. One is 'Educare' i.e., to bring up; the second is 'Educatum' i.e.,to teach or to act of teaching; third is 'Educere' i.e., to draw out; and fourth is 'Educo' i.e., to reduce or to develop within. In the Indian context,'Education' is related to 'Siksha-Vidya', which means administrate, control and enfetter. According to Swami Vivekananda education is a continuous process; it should cover all aspects of life - physical, material, intellectual, emotional, moral, and spiritual. His attitude towards modernization is that the masses should be educated before anything else is done. He wanted to remove from India four major evils likely - priest- craft; poverty; ignorance; and the tyranny of the wise. He tried to make the people of India understood that political and social strength should have their foundations on cultural strength. He has a true vision of the philosophy of education in India in its cultural context.

\section{Concept of CBCS}

Ministry of Human Resource Development (HRD), Govt. of India, has already initiated the process for developing New Education Policy (NEP) in our country to bring out reforms in the Indian education system. UGC participates more actively in developing National Education Policy, its execution and promotion of higher education in our country. The UGC has already initiated several steps to bring equity, efficiency and academic excellence in National Higher-education System. The important ones include innovation and improvement in course curricula, the introduction of a paradigm shift in learning and teaching pedagogy, examination and education system. The CBCS provides an opportunity 
for the students to choose courses from the prescribed courses comprising a core, elective/minor or skill-based courses. The courses can be evaluated following the grading system, which is considered to be better than the conventional marks system. Therefore, it is necessary to introduce a uniform grading system in the entire highereducation in India. This will benefit the students to move across institutions within India to begin with and across countries. The uniform grading system will also enable potential employers in assessing the performance of the candidates. In order to bring uniformity in the evaluation system and computation of the Cumulative Grade Point Average (CGPA) based on student performance in examinations, the UGC has formulated the guidelines to be followed. These guidelines shall apply to all undergraduate and postgraduate level degree, diploma and certificate programs under the credit system awarded by the Central, State and Deemed to be universities in India.

\section{RESEARCH METHODS}

\section{Research Design}

According to Agburu, 2007, survey is an investigation conducted over a large area to find-out what problem exists as at the time of research in a given area. The survey research design was considered appropriate since data would be

collected from elements or subjects without imposing any condition or treatment on them. Therefore, the research can only describe, explain and/or predict events without interfering in their functioning. The adoption of this research design allows for the use of questionnaires by the researcher as a data collection instrument and it is cost-effective. The study seeks to analyze all aspects which will affect our education system in rural West Bengal for higher-education.

A simple random sampling technique has been used for the selection of higher education institutions. The area of study is limited in South 24 Parganas district of West Bengal and the district divided the whole district into five sub-divisions namely Alipur-sadar, Diamond Harbour, Kakdwip, Baruipur, and Canning. As this district is very large, so, few gram-panchayats have been considered from only two sub-divisions. Those gram-panchayats are Maheshtala, Budge-Budge, Nodakhali, Gobindapur, Burul, Uttar Roypur, Chandua, Alampur, Poali, Rania, Hauri, etc. from Alipur-sadar sub-division and Vadura, Fatehpur, Bot-tala, Patol, Devipur, Doulatpur, Folta, Horindanga, Kodalia, Rajarampur, etc from Diamond Harbour subdivision. Within this area, few higher-education institutes were selected randomly.

Table 2: Sub-divisions, Blocks, and Municipalities

\section{South 24 Parganas District}

\begin{tabular}{c|c|c|c|c|c|c|c|c}
\hline $\begin{array}{c}\text { Diamond Harbour } \\
\text { sub-division }\end{array}$ & \multicolumn{2}{c}{$\begin{array}{c}\text { Baruipur sub- } \\
\text { division }\end{array}$} & \multicolumn{2}{c|}{$\begin{array}{c}\text { Kakdwip sub- } \\
\text { division }\end{array}$} & $\begin{array}{c}\text { Alipore-sadar sub- } \\
\text { division }\end{array}$ & \multicolumn{2}{c}{$\begin{array}{c}\text { Canning sub- } \\
\text { division }\end{array}$} \\
\hline $\begin{array}{c}\text { Block } \\
(09)\end{array}$ & $\begin{array}{c}\text { Municipali } \\
\text { ty }\end{array}$ & $\begin{array}{c}\text { Block } \\
(07)\end{array}$ & $\begin{array}{c}\text { Municipali } \\
\text { ty }\end{array}$ & $\begin{array}{c}\text { Block } \\
(\mathbf{0 4})\end{array}$ & $\begin{array}{c}\text { Block } \\
(\mathbf{0 5})\end{array}$ & $\begin{array}{c}\text { Municipali } \\
\text { ty }\end{array}$ & $\begin{array}{c}\text { Block } \\
(04)\end{array}$ \\
\hline
\end{tabular}




\begin{tabular}{|c|c|c|c|c|c|c|c|}
\hline & (01) & & (03) & & & (03) & \\
\hline $\begin{array}{l}\text { Diamond } \\
\text { Harbour } 1\end{array}$ & $\begin{array}{l}\text { Diamond } \\
\text { Harbour }\end{array}$ & Bhangar 1 & Baruipur & Kakdwip & Bishnupur 1 & Maheshtala & $\begin{array}{c}\text { Basant } \\
\text { i }\end{array}$ \\
\hline $\begin{array}{l}\text { Diamond } \\
\text { Harbour } 2\end{array}$ & - & Bhangar 2 & $\begin{array}{l}\text { Rajpur- } \\
\text { Sonarpur }\end{array}$ & Namkhana & Bishnupur 2 & $\begin{array}{l}\text { Budge } \\
\text { Budge }\end{array}$ & $\begin{array}{c}\text { Canni } \\
\text { ng } 1\end{array}$ \\
\hline Folta & - & Jaynagar 1 & $\begin{array}{l}\text { Joynagar- } \\
\text { Mazilpur }\end{array}$ & $\begin{array}{l}\text { Pathar } \\
\text { Pratima }\end{array}$ & $\begin{array}{l}\text { Budge } \\
\text { Budge } 1\end{array}$ & Pujali & $\begin{array}{c}\text { Canni } \\
\text { ng } 2\end{array}$ \\
\hline Kulpi & - & Jaynagar 2 & - & Sagar & $\begin{array}{c}\text { Budge } \\
\text { Budge } 2\end{array}$ & - & $\begin{array}{c}\text { Gosab } \\
\mathrm{a}\end{array}$ \\
\hline Mograhat 1 & - & Kultoli & - & - & $\begin{array}{c}\text { Thakurpuku } \\
\text { r- } \\
\text { Maheshtala }\end{array}$ & - & - \\
\hline Mograhat 2 & - & Sonarpur & - & - & - & - & - \\
\hline $\begin{array}{c}\text { Mandirabaz } \\
\text { ar }\end{array}$ & - & Baruipur & - & - & - & - & - \\
\hline $\begin{array}{c}\text { Mathurapur } \\
1\end{array}$ & - & - & - & - & - & - & - \\
\hline $\begin{array}{c}\text { Mathurapur } \\
2\end{array}$ & - & - & - & - & - & - & - \\
\hline
\end{tabular}

\section{Sampling Technique}

This is a procedure whereby the study population is divided into strata and sample is randomly drawn according to percentage or proportion of subjects in each stratum (Alamu \& Olukosi, 2008). The population was divided into four settlements to ensure representatives of the various settlements in Makurdi. Thereafter, the various settlements were randomly sampled. The settlements are Wurukum, Wadata, High level and North bank. The strata (settlements) were presumed to be of roughly equal sizes and there is no additional information regarding the variability or distinctions of responses in the strata.

\section{Research Instrument}

In order to elicit information about the particular study in rural West Bengal for education, the researcher structured questionnaire and personal interview. The structured questionnaire was targeted at the teachers, students and guardians. The questionnaire consists of a list of questions relating to the aim and specific objectives of the study and the hypotheses to be verified (Alamu \& Olukosi, 2008). The interview method on the other hand involves asking questions verbally and receiving verbal answers from the respondent. The researcher recorded the verbal answers and asked for additional clarification where necessary.

\section{Administration of Research Instrument}

The questionnaire was personally administrated by the researcher. This method, through time consuming and laborious was adopted to ensure accuracy and reduce refusal, non-responsive or incomplete responses.

\section{Methods Used}

The present study is based on primary and secondary collected from the published reports of newspapers, journals, websites, review of past 
researches and other reports etc... In my study, I have combined three techniques those are the interview method, questionnaire method and literature review method. My investigation for the purpose of the present study is likely to be directed towards collecting necessary data through face to face interview of the teachers, students and guardians. Therefore, the interview method has been adopted to collect necessary information relating to socio-economic conditions, problems faced by the respondents, factors responsible for the success or failure of higher-education. In research, the population refers to a well-defined collection of individuals or objects with similar characteristics or traits (Alamu \& Olukosi, 2008). A population can be finite or infinite. A population is said to be finite if it is possible to count its individuals. Angahar \& Akpa, 1999, defined sample as a limited number of elements selected from a population that is representative of the whole of that population. The sample must have sufficient size to warrant statistical analysis. Accordingly, I have taken interview of 100 rural teachers and 100 rural students and guardians who are engaged in different types of higher-educational activities in the districts of South 24 Parganas of West Bengal.

\section{Validation and Reliability of Research Instrument}

Baridam, 2011, defined validity as the extent to which a test measures what it is expected to measure. The project supervisor made necessary corrections to the questionnaire to ensure the validity of the research instrument. Reliability refers to the degree to which a research instrument produces a stable and consistent results (Phelan \& Wren, 2006). The reliability of the instrument was achieved by pilot testing. The result showed that the instrument was reliable for the research.

\section{Sampling Design}

Avwokeni, 2004, defined sample size is the total number of subjects or individual elements chosen from the population under study. Rural higher-education that is the main source of primary data is collected from the teachers, students, and guardians through a well-structured questionnaire. As the area of study is limited in South 24 Parganas district of West Bengal, I selected 10 gram panchayats in Alipore Sadar Sub-divisions of West Bengal, due to paucity of time. I have selected 20 rural teachers, students and guardians from each gram panchayats by systematic random sampling procedure in order to avoid any bias in our sample selection process. Thus altogether 100 rural teachers and 100 rural students and guardians have been interviewed with the help of a structured questionnaire.

\section{Tools for Analysis}

The only a simple percentage analysis method is used for simplification of the analysis. The primary data collected from the field are analyzed with the help of simple statistical diagram.

\section{RESULTS AND DISCUSSION}

This chapter deals with the analysis and interpretation of the data collected in the field. In order to achieve the objectives of this research work, a total of 300 copies of questionnaire were administered to respondents. However, 258 
respondents were returned their questionnaire, while 58 questionnaires were either defaced or improper filled and were therefore discarded leaving a total 200 properly filled questionnaires.

\section{Data Presentation and Analysis}

The data collected from the field through the use of structured questionnaire. Analysis of data is a process of inspecting, cleaning, transforming and modeling data with the goal of highlighting useful information, suggesting conclusions and supporting decision making. I inspected the data and corrected if any error besides quality check on the collected data. Whole data was thoroughly studied keeping the objectives of research in memory. It has been analyzed that the extreme observations if they were disturbing the distribution. I was very much interested to find-out the percentages between different groups and for that purpose average percentage is calculated on the basis of collected response sheet information by using the percentage formula with a particular item. Purely based on the data collection from the respondents and after applying statistical technique following result was found on the attendance.

YES percent for particular item $=$ Sum of YES response/Total response of a particular item $\times 100$

NO percent for particular item $=$ Sum of NO response/Total response of a particular item $\times 100$
Research Question 1: Different

government schemes to encourage

higher-education

\begin{tabular}{ccc}
\hline & Yes & No \\
\hline Teacher & $62 \%$ & $38 \%$ \\
Student \& & $54 \%$ & $46 \%$ \\
Guardian & & \\
\hline
\end{tabular}

From the above table it has been seen that to encourage poor students in higher-education through different government facilities has a great influence. 62percent teacher respondents believed that through schemes-facilities students will be motivated and they will come to different colleges and universities for higher-education and rest teachers have given answer 'NO'. Out of students and guardians, 54percent answered to support the statement and balance not supported.

\section{Research Question 2: Increase in the} enrolment ratio of higher-education and reduce the drop-out ratio

\begin{tabular}{ccc}
\hline & Yes & No \\
\hline Teacher & $73 \%$ & $27 \%$ \\
$\begin{array}{r}\text { Student \& } \\
\text { Guardian }\end{array}$ & $65 \%$ & $35 \%$ \\
\hline
\end{tabular}

From the above table it has been seen that government policies has a great role to increase the enrolment ratio and to reduce the dropout ratio. 73 percent teachers believed that facilities had been resulting effectively in while 27 percent believed that no change had taken in said ratios by the said 
Vol. 1, No. 2, November 2019, pp. 108-116

scheme. In the same way 65 percent students and guardians believed that schemes had improved the said situations and 35 percent did not believe on that.

Research Question 3: Government schemes influencing empowerment

\begin{tabular}{rll}
\hline & Yes & No \\
\hline Teacher & $80 \%$ & $20 \%$ \\
Student \& & $68 \%$ & $32 \%$ \\
Guardian & & \\
\hline
\end{tabular}

Most of the respondents agreed that policies have a great influence in empowering. 80 percent teachers and 68percent students and guardians believed that and balance did not believe that schemes can influence empowerment. This may be one of the important parameter of social empowerment.

\section{Research Question 4: Role of schemes in elimination of discrimination i.e., gender equality}

\begin{tabular}{ccc}
\hline & Yes & No \\
\hline Teacher & $75 \%$ & $25 \%$ \\
$\begin{array}{c}\text { Student \& } \\
\text { Guardian }\end{array}$ & $60 \%$ & $40 \%$ \\
\hline
\end{tabular}

From the above table it has been seen that government policies has an effect to bring gender equality and larger section of respondents agreed that. All students are having their facilities irrespective of their sex and this is very common picture in maximum institutions-organisations. At least in this case there is no significant discrimination.

\section{Research Question 5: Caste reservation} is necessitates in higher-education

\begin{tabular}{|c|cc}
\hline & Yes & No \\
\hline Teacher & $51 \%$ & $49 \%$ \\
$\begin{array}{c}\text { Student \& } \\
\text { Guardian }\end{array}$ & $55 \%$ & $45 \%$ \\
\hline
\end{tabular}

Almost 50 percent of the all type of respondents agreed that caste reservation ensuring the SC/ST/OBC students to grow their interestenrollment in higher-education and balance 50percent did not agree in this issue. Obviously I would mention that it depends on the basis of nature and location of area of organisations-institutions.

\section{Research Question 6: Financial-} economical reservation is necessitated in higher-education

\begin{tabular}{ccc}
\hline & Yes & No \\
\hline Teacher & $52 \%$ & $48 \%$ \\
Student \& & $54 \%$ & $46 \%$ \\
Guardian & & \\
\hline
\end{tabular}

Almost 50 percent of all types of respondents agreed that financial reservations ensuring those students who are economical disable/back-warded to grow their interest-enrollment in higher-education and balance 50percent did not agree on this issue. Obviously I would mention that it depends on the basis of nature and location of area of organisations-institutions.

\section{CONCLUSION}

It may be concluded that on the basis of above criteria the effectiveness is gradually increasing in 
overall development of higher-education of our state and different schemesare very important in educational reform. Still our government is facing some problems related to policies but that should be resolved and organized shortly, I hope. It can be said that different schemes-policies-facilities though has been implemented but is not being monitored properly. The schemeshave given one way provision i.e., throughfeedback form, from students and parents should be taken regularly. In this study only few institutions of a particular district have been considered so, it is not possible to get the whole picture of the state in this regard, I think this is one of the important limitations. To remove the above limitation further study may be done by considering larger sample size. However, institutions of higher learning ought to be a major force in society not only for producing leaders in science and technology, but also for downstream channeling of progressive social, moral and political values while keeping in perspective temporal realities and spatial constraints. Higher-education reform efforts aim at independent, strong and objective analysis of ground reality. The central objective of the $12^{\text {th }}$ plan is now focused on Expansion of enrolment in highereducation with inclusiveness, quality and relevant education and supported by necessary academic reforms in the university and college system in India. It is equally necessary that individual state and central government also take similar initiative in their respective state plan and develop policies to address the above issues at war footing. The statics of growth in institutional capacity do not capture the twin problem of quality and employability. In order to transform itself from developing to developed Indian educational system needs to employ qualitative faculty and bring about major reforms that include social justice, competence academic freedom, autonomy versus accountability and decentralization versus centralization. Students and families are increasingly seeking education which may improve their prospects of employability and upward mobility. Institutions and policy-makers need to listen to the qualitative dimension of the demand and adapt to it to remain relevant, competitive and sustainability through field survey. Again I say that it is a manufacturing business.

\section{REFERENCES}

'Higher-education in India: The Need for Change', ICRIER WorkingPaper, Indian Council for Research on International Economic Relations: No. 180, Agarwal, P. (2006)

'Educational Philosophy of Swami Vivekananda', S.V. Bharathi, Discovery Publishing House, 01-Jan2010

Report of the working group on higher-education for the XII five year plan, Gol, HRD, Department of higher-education, September, 2011

'More students opt for higher-education, but even more drop out: Survey', Varma, Subodh, (2013), The Economic Times - Education, August, 31st 
'Higher-education in Rural Areas - Problems and http://mhrd.gov.in

Prospects - A Special Reference to India', http://www.ugc.ac.in

Bhushan, Govind N, (2014) Multidisciplinary http://icssr.org

Scientific Review, Vol. 1

www.rural.nic.in

All India Survey on Higher-education 2017-18, Gol,

Ministry of HRD, Department of higher-

education, 2018 